\title{
Social Media on Participation of Young Generation in Electoral Politics: A Case Study
}

\author{
Md. Shahabul Haque ${ }^{1 *}$, Sharmin Akther Liza ${ }^{2}$ \\ ${ }^{1}$ Department of Political Studies, \\ Shahjalal University of Science \& Technology, Sylhet, Bangladesh \\ ${ }^{2}$ Department of Political Studies \\ Brindaban Government College, Habiganj, Bangladesh \\ *Corresponding author's email: shahabu14 [AT] yahoo.com
}

\begin{abstract}
It is assumed that excessive usage of social media among young generations, i.e., students of universities make them more socially integrated and politically informed. Political parties use media as well as social media to portrait candidates and their various issues which attract mass people. Though there are some studies around, which validates these influence of social media on participation of young generation in electoral politics is done previously for some countries of world but yet, for the country Bangladesh, there is no such study still existing which reveals these issues with explanatory-descriptive analysis, particularly done for any specialized public university, where internet is more viable than to other kinds of universities, because of the additional attention is given to information and communications technology there. Mixed method has been applied to make the study more reliable. The study here perhaps is done with a format of structured questionnaire and Focus Group Discussion; simple random sampling and cluster sampling to fulfill the subsisting gap thus have found the most common kinds of websites used by respondents, average duration of them in daily basis, whether on other hand, have assessed that effectiveness of social media to inspire young generation in political participation.
\end{abstract}

Keywords - Social Media, Young Generation, Electoral Politics, Political Participation

\section{INTRODUCTION}

Bangladesh emerged as an independent and self-governing country at South Asia on $16^{\text {th }}$ December, 1971 following a nine-month war of liberation. Having come out of the grips of almost 200 years of British colonial rule, the country had endure a further 24 years of internal colonial rule under the banner of united Pakistan with Bangladesh, the then East Pakistan (Karim, 2004). Bangladesh is a country of third world. It is one of the largest deltas of the world with a total area of 1,47,570 square kilometers. With a unique communal harmony, Bangladesh has now a population of about 149.77 million, making it one of the densely populated and low income generating countries of the world. Like other developing countries, Bangladesh was late in introducing internet technology and so that the internet came in Bangladesh during 1993 and online internet service began in 1996. By social media, people can now communicate and interact with each others in various new ways through text, photos and even audio or visual means. The main focus of this paper is to identify the influence of social media on electoral politics among the young generation.

The internet penetration rate in Bangladesh is as low as $6.86 \%$, compared to Thailand $928.84 \%$, India $19.19 \%$, Pakistan $10.84 \%$, Nepal $12.13 \%$, Indonesia $16.72 \%$. No doubt, the internet is a revolutionary method of communication. Of all other media, people especially young people like computer networking or internet most. For study, sharing caring, and communicate with others students spent a large part of the day on internet. This can mean checking Facebook updates, posting on Twitter or just keeping up to date with a friend's fickler stream. Among 34 public and 54 Government approved private universities in Bangladesh, and all of them have internet access.

Over the time, new technologies have changed the way election campaigns are conducted and how people vote. Researcher in the 1940s found that the factors affecting voter choice were: party affiliation, social group allegiance, the candidate's personality and consideration of other issues. Now a days, this order has been changed. Social science research indicates that the candidate's personality, their position on issues, party affiliation and group membership are now deciding factors. Many scholars attribute this reversal to the influence of media that allows candidates to communicate directly the voters and of media reportage that concentrates on the candidate's personalities over other issues. There are different types of media that include, print media like news paper, books, magazines, pamphlet; 
electronic media like television, radio social media like internet which include Facebook, Twitter, You tube, Instgram, Blogg, Vimu etc. Finally, social media is the most popular network system in the world wide. It would not be equally applicable for all of the countries in the world. Developed countries adopt modern technology and largely use social network. On the other hand, developing countries are continually facing many socio-economic and political problems. Week political system and political unrest are the common features in these countries. In developed countries social media is a popular instrument for electoral campaigning and it helps raise the number of young voter's in political participation. For a developing country, like Bangladesh popularity of social media increased gradually all over the country. On the other hand, rate of internet users increased rapidly. It may be mentioned here that that social media should be focused on true and reliable information for audience. Sometimes media expose bias information about politics and political leader. Often social media controlled by the government. For this reason media cannot provide real scenario and situation of politics in Bangladesh. This study investigates that how the people accept the news of media and how they get influenced to practice in politics.

The main objective of the study is to know the influence of social media on participation of young voters in electoral politics. In order to fulfill the main objective, the research paper specifies: (1) to find out the label of interest on electoral participation (2) to assess the changes of perception about the electoral participation. (3) to examine how the young voter is influenced by social media.

\section{REVIEW OF THE LITERATURE}

Lovin (1979) worked on Individual Political Participation: The effects of social structure and communication behaviour. In this study researcher attempting to explained theories of individual political participation have assumed that mass media use in recursive cause of such participation. Researcher argued the possibility of indirect at relationship between mass media and political participation. It is examined by Two stage least squares technique. This survey conducted on the South Carolina uses both male and female sub sample to show the impact of social media. But the researcher did not emphasise the impact of internet on voter's participation.

Best and Krueger (2005) analysed the representation of internet political participation. In this paper researchers discussed about political participation, internet use, public opinion, political representation and Resource Theory. Researchers use a wide spectrum of political opinion question to determine whether online participators opinion reflect or distort those of general population. But researcher did not show their concern about young generation. Where, most of the young people use internet in regular basis.

McClurg (2006) examined that the electoral relevance of political talk and effects of social network in political participation using survey method data would be gathered during 1996 Presidential election. He shown that the level of political sophistication in a person's social network expertise a positive influence on participation. This study mainly emphasised the linked between network and involvement. There have some problems in this study. How the network was created is not made clear.

Salsebary (1975) on her research paper discussed about political participation, individual political interest, individual political behavioural differences, democratic participation, and modes of participation. But she had no interest about determinants of the study like; income, age education, religion family ideology and mass media. Determinants play an important role to motivated people in political participation.

Tolbert and Neal (2003) investigated the unravelling effects of the internet on political participation in the American National Election 2000. Survey method is used in this study. Result found that $22 \%$ of the voter used television, $39 \%$ used newspaper, and 11\% used internet. Result indicated that internet user's percentage is very negligible. Here internet does not create social and political isolation in America. So the results have some limitation.

Clark and Everhart (2007) examined the relationship between quantity of internet use and positive effect of internet use by college freshmen. An online student survey of behaviours and concerns was administrated to 182 college freshmen of Northeastern University. Results showed that, male students who were online more than 10 hours per week expressed significantly less concern about their emerging role definitions and autonomy. Female students who used the internet for more than 10 hours per week reported significantly less concern about being sad or depressed. Results indicated, time spent online helps college freshmen to develop their communication skills. There is a major limitation in this paper that must be considered. Researchers described internet as a perspective of positive communication and coping skills, but they does not focused on political interest of internet users.

Irum (2006) examines the role and impact of a diverse range of media outlets on various aspects of governance in Bangladesh. It looks at an interlinked set of issues encompassing the national media's role as a state watchdog and shaper of public opinion, and how this is enhanced or hindered by its lack of capacity, ownership structure and internal governance. This study includes, there are currently a total of 743 registered news publications with an official total circulation of 6,107,616 (2006). Daily newspapers are published in sixty districts out of sixty-four and 45 districts have 
regularly published weeklies. Reports state that only a total of 20-22 daily newspapers are regularly published. The study found that $41 \%$ of households own a TV in 2006, as compared to $8 \%$ in 1995 . The survey also states that over $65 \%$ of Bangladeshis aged 15 or over watch TV at least once a week. However, media practitioners and observers at all levels expressed concern over both the print and electronic media licensing system and the poor implementation of a flawed regulatory framework. This study has some limitation. This study emphasises only electronics media and print media. But, he would not emphasise the impact and role of social media on governance of Bangladesh.

\section{CONCEPTUAL FRAMEWORK}

In this study Participation of young generation in electoral politics is considered as dependent variable and social media considered as independent variable. Here Participation of young generation in electoral politics means young people are influenced by social media in electoral politics where the indicators are voting behaviour, political communication, electioneering campaigning, public opinion, political consciousness.

\subsection{Independent variable}

Social media: Social media are Internet sites where people interact freely, sharing and discussing information about each other and their lives, using a multimedia mix of personal words, pictures, videos and audio. There are different types of social media, which may include; Internet, Facebook, Twitter, You Tube, Blogging, What's app, Viver, Vimeo, Line, My people etc.

\subsection{Dependent variable}

(a) Young generation: According to the National Youth Policy 2003 in Bangladesh, Youth as citizens aged between 18-35. According to the Constitution of the People's Republic of Bangladesh, Article 122 (2)(b)- A person shall be entitled to be enrolled on the electoral roll for a constituency delimited for the purpose of election to the parliament, if he is not less than eighteen years of age. In this research, young voter in universities whose age is 18-35 considered eligible for the study.

(b) Political participation: Political participation is any activity that shapes, affects, or involves the political sphere. Political participation ranges from voting attending a rally to committing an act of terrorism to sending a letter to a representative.

(c) Electoral politics: Electoral politics refers to Election related politics. According to Oxford Advanced Learner's Dictionary, Election means choosing by vote. Politics means the science of government and the management of political affairs.

\section{METHODOLOGY OF THE STUDY}

In this research, it is attempted to identify internet influenced of young voter in political participation. Mixed method has received to achieve the objective of the study. Qualitative study has been followed to conduct Focus Groups Discussion and Quantitative study has been followed to survey method. The study chose to use explanatory-descriptive design. The primary data are collected from 150 respondents through Structured Questionnaire. Here 125 students and 25 Teacher are interviewed where male member and female member are equal. There is a Focus Group which consists of eight members in total among them. In this research, secondary data are collected from various Books, Journals, Magazines, National and International Research reports and internet etc.

Shahjalal University of Science and Technology (SUST), Sylhet is the research area. In this research, each selected student of SUST is considered as unit of as unit of analysis from the total population. Simple random sampling method and cluster sampling is followed to conduct this study. Cluster sampling method is used because it is necessary to select the representative of the students of the existing semester of university. It is also important to enlist the new and old voter, who have casts their vote one, twice, trice or more times. Collected data are characteristically classified and tabulated. 


\section{RESULTS}

Table 1: Types of Internet services

\begin{tabular}{|c|c|c|c|c|c|}
\hline & & Frequency & Percent & Valid Percent & Cumulative Percent \\
\hline \multirow[t]{5}{*}{ Valid } & News & 12 & 8 & 8 & 8 \\
\hline & Chatting & 7 & 4.7 & 4.7 & 12.7 \\
\hline & Social networking & 101 & 67.3 & 67.3 & 80 \\
\hline & Internet surfing & 30 & 20 & 20 & 100 \\
\hline & Total & 150 & 100 & 100 & \\
\hline
\end{tabular}

From the derived data of Table 1, we have found that, $8 \%$ of the respondents reading news most, $4.7 \%$ chatting most, $67.3 \%$ using social networking sites most, $30 \%$ are doing internet surfing. Results indicate that social networking sites are most common and popular for young generation.

Table 2: Frequency has most uses sites of social media

\begin{tabular}{|l|c|c|c|c|}
\hline & Frequency & Percent & Valid Percent & Cumulative Percent \\
\hline Valid Facebook & 96 & 64 & 64 & 64 \\
What's app & 13 & 8.7 & 8.7 & 72.7 \\
Viber & 12 & 8 & 8 & 80.7 \\
Twitter & 2 & 1.3 & 1.3 & 100 \\
Others & 18 & 100 & 100 & 18 \\
Total & 150 & 18 & \\
\hline
\end{tabular}

Table 2 states among the respondents, $64 \%$ uses facebook, $8.7 \%$ uses what's app, $8 \%$ uses viber, $1.3 \%$ using twitter and $18 \%$ using other sites.

Table 3: Medium to communication with friends and familiar

\begin{tabular}{|c|c|c|c|c|c|}
\hline & & Frequency & Percent & Valid Percent & Cumulative Percent \\
\hline \multirow[t]{5}{*}{ Valid } & Face to face & 21 & 14 & 14 & 14 \\
\hline & Phone & 20 & 13.3 & 13.3 & 27.3 \\
\hline & Social media & 80 & 53.3 & 53.3 & 80.7 \\
\hline & All of them & 29 & 19.3 & 19.3 & 100 \\
\hline & Total & 150 & 100 & 100 & \\
\hline
\end{tabular}

Table 3 states, for communicating friends $14 \%$ of respondents use face to face interaction, $13.3 \%$ use phone and $53.3 \%$ use social media and $19.3 \%$ uses all of them.

Table 4: Frequency of meeting with friends

\begin{tabular}{|c|c|c|c|c|c|}
\hline & & Frequency & Percent & Valid Percent & Cumulative Percent \\
\hline \multirow[t]{4}{*}{ Valid } & Every day & 103 & 68.7 & 68.7 & 68.7 \\
\hline & Once in a week & 37 & 24.7 & 24.7 & 93.3 \\
\hline & Once in a month & 10 & 6.7 & 6.7 & 100 \\
\hline & Total & 150 & 100 & 100 & \\
\hline
\end{tabular}

We found from derived data of Table 4 that, $68.7 \%$ respondents meet with friends every day, $24.7 \%$ respondents meet once in a week and $6.7 \%$ meet once in a month. 
Table 5: Party activism in university campus

\begin{tabular}{|cc|c|c|c|c|}
\hline & Frequency & Percent & Valid Percent & Cumulative Percent \\
\hline \multirow{2}{*}{ Valid } & Yes & 49 & 32.7 & 32.7 & 32.7 \\
& No & 101 & 67.3 & 67.3 & 100 \\
& Total & 150 & 100 & 100 & \\
\hline
\end{tabular}

Table 5 indicating that, $32.7 \%$ respondents are politically active in university campus and $67.3 \%$ have no political activity in university campus

Table 6: Frequency of attend in election

\begin{tabular}{|c|c|c|c|c|c|}
\hline & & Frequency & Percent & Valid Percent & Cumulative Percent \\
\hline \multirow[t]{5}{*}{ Valid } & 0 & 60 & 40 & 40 & 40 \\
\hline & 1 & 56 & 37.3 & 37.3 & 77.3 \\
\hline & 2 & 29 & 19.3 & 19.3 & 96.7 \\
\hline & 3 or more & 5 & 3.3 & 3.3 & 100 \\
\hline & Total & 150 & 100 & 100 & \\
\hline
\end{tabular}

Table 6 states, among the students, $40 \%$ not participate any election (those are new voter), $37.3 \%$ attend election only one time and $19.3 \%$ attend election two times and $3.3 \%$ attend election three or more times.

Table 7: Frequency has select a candidate in election

\begin{tabular}{|c|c|c|c|c|c|}
\hline & & Frequency & Percent & Valid percent & Cumulative percent \\
\hline \multirow[t]{4}{*}{ Valid } & Ideology of candidate & 95 & 63.3 & 63.3 & 63.3 \\
\hline & Symbol of candidate & 49 & 32.67 & 32.67 & 96 \\
\hline & Qualification of candidate & 6 & 4 & 4 & 100 \\
\hline & Total & 150 & 100 & 100 & \\
\hline
\end{tabular}

Table 7 shows that, $63.3 \%$ select a candidate for ideology, $32.67 \%$ select a candidate for symbol and $4 \%$ select a candidate for his or her qualification.

Table 8: Medium to know about political information of respondents

\begin{tabular}{|c|c|c|c|c|c|}
\hline & & Frequency & Percent & Valid Percent & Cumulative Percent \\
\hline \multirow[t]{5}{*}{ Valid } & Newspaper & 42 & 28 & 28 & 28 \\
\hline & Television & 16 & 10.7 & 10.7 & 38.7 \\
\hline & Social media & 64 & 42.7 & 42.7 & 81.3 \\
\hline & All of them & 28 & 18.7 & 18.7 & 100 \\
\hline & Total & 150 & 100 & 100 & \\
\hline
\end{tabular}

Table 8 indicating that, $28 \%$ respondent know about political information through reading newspaper and $10.7 \%$ know about political information through watching television, $42.7 \%$ respondents know about political information through social media and $18.7 \%$ know about political information through all of media sites. 
Table 9: Medium to discuss about political issues with friends and familiar persons

\begin{tabular}{|ll|c|c|c|c|}
\hline & Frequency & Percent & Valid Percent & Cumulative Percent \\
\hline \multirow{2}{*}{ Valid } & Face to face & 36 & 24 & 24 & 24 \\
& Phone & 12 & 8 & 8 & 32 \\
Social media & 59 & 39.3 & 39.3 & 71.3 \\
All of them & 43 & 28.7 & 100 & 100 \\
Total & 150 & 100 & 100 & \\
\hline
\end{tabular}

The Table 9 states that, for discussing political issues with friends $24 \%$ of respondents discuss face to face, $8 \%$ use phone and $39.3 \%$ use social media and $28.7 \%$ respondent like to talk about political issues with friends and familiar persons through all of the communication sites.

Table 10: Frequency of update political information

\begin{tabular}{|c|c|c|c|c|c|}
\hline & & Frequency & Percent & Valid Percent & Cumulative Percent \\
\hline \multirow[t]{5}{*}{ Valid } & Daily & 55 & 36.7 & 36.7 & 36.7 \\
\hline & Weekly & 58 & 38.7 & 38.7 & 75.3 \\
\hline & Monthly & 29 & 19.3 & 19.3 & 94.7 \\
\hline & Not interested & 8 & 5.3 & 5.3 & 100 \\
\hline & Total & 150 & 100 & 100 & \\
\hline
\end{tabular}

Table 10 shows that $36.7 \%$ update political information daily and $38.7 \%$ update political information per weekly and $19.3 \%$ update political information per monthly and $5.3 \%$ are not interested to update political information.

Table 11: Political involvement in facebook

\begin{tabular}{|c|c|c|c|c|c|}
\hline & & Frequency & Percent & Valid Percent & Cumulative Percent \\
\hline \multirow[t]{4}{*}{ Valid } & Sharing post & 41 & 27.3 & 27.3 & 27.3 \\
\hline & Only like or comment & 97 & 64.7 & 64.7 & 92 \\
\hline & Not interested & 12 & 8 & 8 & 100 \\
\hline & Total & 150 & 100 & 100 & \\
\hline
\end{tabular}

Table 11 indicating that, $27.3 \%$ respondent sharing politics related status in face book and $64.7 \%$ give just like or comment another friends status and $8 \%$ not interested to sharing any politics related status or like, comment.

Table 12: Frequency has trust in political information through social media

\begin{tabular}{|c|c|c|c|c|c|}
\hline & & Frequency & Percent & Valid Percent & Cumulative Percent \\
\hline \multirow[t]{4}{*}{ Valid } & Yes (with justification) & 74 & 49.3 & 49.3 & 49.3 \\
\hline & Partial & 60 & 40 & 40 & 89.3 \\
\hline & No & 16 & 10.7 & 10.7 & 100 \\
\hline & Total & 150 & 100 & 100 & \\
\hline
\end{tabular}

Table 12 shows that, $49.3 \%$ believe political news in social media and $40 \%$ believe in partially because most of the times social media focus on the bias news and $10.7 \%$ have no trust in political information. 
Table 13: Frequency has changes political opinion by campaigning of election through social media

\begin{tabular}{|c|c|c|c|c|c|}
\hline & & Frequency & Percent & Valid percent & Cumulative percent \\
\hline \multirow[t]{4}{*}{ Valid } & Yes & 76 & 50.7 & 50.7 & 50.7 \\
\hline & No & 20 & 13.3 & 13.3 & 64 \\
\hline & Partially & 54 & 36 & 36 & 100 \\
\hline & Total & 150 & 100 & 100 & \\
\hline
\end{tabular}

Table 13 indicating that, $50,7 \%$ respondent changes political opinion by campaigning of election through social media, $13.3 \%$ respondent partially changes their political opinion and $36 \%$ has never changes political opinion through social networking.

Table 14: Feeling interest to attend in election through social networking

\begin{tabular}{|cc|c|c|c|c|}
\hline & Frequency & Percent & Valid Percent & Cumulative Percent \\
\hline \multirow{2}{*}{ Valid } & Yes & 110 & 73.3 & 73.3 & 73.3 \\
& No & 40 & 26.7 & 26.7 & 100 \\
& Total & 150 & 100 & 100 & \\
\hline
\end{tabular}

Table 14 indicating that, In case of feeling interest to attend in election through social networking $73.3 \%$ and $26.7 \%$ participate in the election by general view.

Table 15: Frequency has like to electioneering campaigning through social media

\begin{tabular}{|cl|c|c|c|c|}
\hline & Frequency & Percent & Valid Percent & Cumulative Percent \\
\hline \multirow{2}{*}{ Valid } & Yes & 116 & 77.3 & 77.3 & 77.3 \\
& No & 34 & 22.7 & 22.7 & 100 \\
& Total & 150 & 100 & 100 & \\
\hline
\end{tabular}

Table 15 indicating that, $77.3 \%$ respondents like to electioneering campaigning through social media and $22.7 \%$ has no likeness to electioneering campaigning through social media.

\section{FOCUS GROUP DISCUSSION}

The focus group has been conducted in the students of SUST present as participants of discussion. The dialogue was divided into four broad themes so as to facilitate a focused discussion. These four themes were as follows: a) The positive impact of social media on society b) The negative impact of social media on society c) Does young people interested to know about political affairs through social media and d) Does young people change their political opinion through social networking. Result of focus group discussion is presented below.

One of the group members (25) states, Social media is so most common in our society that almost everyone is connected to it. We post almost every aspect of our life on social media. Then social networks sprang up and the whole idea of friendship changed once more and forever. It's entirely possible to have hundreds of friends on Face book. Moreover, million of books, journals and other material are available through the internet. It can allow any types of information. The Internet makes possible for business to do affair with their clients and customers.

Another one (25) states, the addiction to online social networks can disturb a person's way of living and professional activity. Anybody can easily upload pornographic material for commercial purpose or just for fun. The young minds of children will be corrupted through their exposure to things which are reserved for adults. Very known personalities and politicians are also victimized by opportunistic and malicious person who want to discredit others using their personal encounters.

Another one (25) said, "He read newspaper regularly in internet. He likes to update the news of the political issues, function of the political parties, activities of leader and manifesto of election. He pays vote the party which will work for the development of our country. Social media make constructive background of the opinion because they maintain 
consequences of news and for this reason people know about the fact of the news. He has to change my political opinion through the news of social media. When we spend time in social networking, we discuss about political issues. We have to change our political opinion through social networking.

One of the group members (24) states, civil society groups and conscious folk of the country are also using social media to facilitate political debates, corruption and mismanagement, irrelevant speeches of ministers, government officials and head of different autonomous bodies of the country. Facebook pages played a major role in terms of promoting the campaigns. People with mobile phones and digital cameras uploaded photos and give the status on different incidents the police and law enforcing agency's people harassing citizens or upload the activities of government ruled political parties mismanagement a and illegal power-practicing. So it helps one to change his or her perception about politics.

Another one (25) states, he could share some positive stories in Bangladesh, there are number of emergency need for blood were collected through social networking site facebook and group SMS and contribute to safe lives. There are number of public movements could become successful through facebook grouping and status posted by someone who already make a positive impression in the social networking in the country. The movement includes Rokeya Bahini's movement in protest of recent garment fire that killed hundred, justice for killing of Journalist Couple Sagor-Runi movement, movement against corruption, demand for safe road, and protest against attack on minority in Ramu. The most successful event was to raise voice against the husband of a Dhaka University teacher, who was tortured by her husband.

Another one (25) states, we share our political view with familiar persons and friends. We have to access in different sites of news link in internet. We spend a little time for watch television and reading newspaper. Most of the time, he read online newspaper. Daily he knows about the present situation of Government and also can know the history of politics and political parties, function of the political parties, their future plan and the policy of the Government. All the information about national politics and international political affairs is also known to him for this facility of using internet. We find politics related information flow thoroughly. So it can help us to change our voting behaviour.

Another one (25) states he has share as with any new technology, everyone is always talking about the negative side effects of the internet and saying how it ruins real face to face relationship, fills our minds with filth and damages our eyes and melts our brains. Internet makes a social networking system where young people passed their free time with friend. It can also help us to study.

Another one (26) states, the internet is so popular nowadays that almost anyone uses it. It is accessible by almost any person who tries to connect to one of its central from main networks. Moreover, it can be accessed by users of any age and condition. But Illegal or inappropriate materials can be found in the internet which break down the base of morality in our society.

\section{INTERPRETATION}

It has found the study that social media is very popular networking systems for the respondents. As a student or a teacher of public Science and Technology University, each and every person has to access in internet. Most of the respondents use social media for social networking and facebook is most popular social networking site for respondents and most of the respondents meet with their friends and familiar through social media in daily basis.

After the above study we see that, the social media plays a major role in keeping the citizenry side by side of current events and raising awareness of various issues in any society. It also has an extremely significant impact on the young's views and way of thinking. It plays an indispensable role in the proper functioning of a democracy. Yet the social media also have other roles in enabling full young participation in elections. The growth of the Internet has garnered great significance during the last few years, especially in its role of informing voters on electoral issues. Social networking is educating young voters on how to exercise their democratic rights. It is providing a platform for the political parties and candidates to communicate their message to the electorate. It is also providing a platform for the public to communicate their concerns, opinions, and needs, to the parties or candidates, the government, and to other voters, and to interact on these issues. Internet is scrutinizing the electoral process itself, including electoral management, in order to evaluate the fairness of the process, its efficiency, and its probity. Social networking is allowing the parties and candidates to debate with each other. By providing information, as far as possible, avoids exciting language, helping to prevent electionrelated violence. The social media are not the sole source of information for young voters, but in a world dominated by mass communications, it is increasingly the social media that determine the political agenda, even in less technologically developed countries. Young people interested on internet because it reduces the cost of information and increase its efficiency. It strengthens young participation in democratic processes. So, the benefits of using the Internet in electoral processes are evident from this study. 


\section{CONCLUSION AND RECOMMENDATION}

The rapid growth of new technologies has changed the communication process between people and has also reduced the cost of communication for individuals. Today's world is now changing by making people advance in networking system. The internet puts the world at a person's fingerprints. With a parallel connection with this notion, findings from this study suggest that young generations are highly involved in various kinds of online activities such that spending times by reading online news, chatting with friends, using social networking sites, doing internet surfing and doing other activities, where, simultaneously it is revealed here, that respondents use above mentioned online services regular basis. Each and every newspaper has a online link in internet. Most of the respondent are know about this matter where they seeing headlines of news at a glance. At last says that, most of the respondents are influenced by the social media in political participation. And some of them are partially influenced. Some recommendation on the use of social media in the socio-political development of Bangladesh that:

- Social media freedom is fundamental in democracy therefore it should be non-negotiable.

- Social media must report the truth without undue misrepresentation of facts, sensationalism, propaganda and bias.

- In reporting, the social media must take cognisance of national security and the welfare of the people.

- Social media practitioners must not be influenced by the interests of ownership, both government and corporate.

- Display or transmission of pornographic and violent social media materials should be controlled to reduce negative influence on societies.

- More social media outfits should be established in rural communities to facilitate development and provide them more access to information.

- Social media Institutes should be established to coordinate the activities of both domestic and international media in order to reduce the incident of false or negative reporting.

- The main obstacle to using the Internet in Bangladesh is its distribution. The Internet is still an urban privilege because internet connections are more concentrated in urban areas, particularly in and around Dhaka. Mobile operators are providing substantial services in and outside urban areas using 3G/EDGE or WiMax.

\section{REFERENCES}

[1] Tolbert, C. J. and Neal, S. M. C. (2003). Unraveling the effects of the internet on political participation. Sage Publication.

[2] Clark, E. A. \& Everhart, D. (2007). Positive Effects of Internet Use by College Freshmen. The New School Psychology Bulletin. 5 (2): pp 31-36.

[3] Lovin, L. S. (1979). Individual political participation: The effects of social structure and communication behaviour. University of California Press, USA.

[4] Salisbury, R.H. (1975). Research on political participation, Midwest journal of political science, 19(2): 323-341.

[5] Best, S. J. and Krueger, B.S. (2005). Analyzes the representativeness of internet political participation. Springer Publication.

[6] McClurge, S. D. (2006). The electoral relevance talk: examining Disagreement and expertise effects in social network on political participation. Sage Publications.

[7] Irum, S. A. (2006). Governance and the Media. Available at http://www.igs-bracu.ac.bd/user files/file/archive_file/governance\%20 and\%20the\%20Media. [Date accessed 17/01/2014]

[8] Karim W. (2004). Election under a caretaker Government: an empirical analysis of the October2001 Parliamentary Election in Bangladesh. The university press Limited, Dhaka. 